acquired or congenital immune defects. In addition to immunosuppression, other factors including EpsteinBarr virus infection, chronic antigen stimulation, and proto-oncogenes, have been implicated in the pathogenesis of the different clinical and histopathological manifestations of AIDS related non-Hodgkin's lymphoma, whereas human herpes virus type 8 may be an infectious cofactor which is required for all forms of Kaposi's sarcoma. ${ }^{5}$

Our data indicate that patients cease to be at risk of Kaposi's sarcoma once immune function has been improved by combination therapy. Conversely, patients with a history of severe immunodeficiency continue to be at risk of non-Hodgkin's lymphoma, despite antiretroviral combination therapy. Although the initiation of carcinogenesis requires an immunodeficient state, the factors promoting the development of non-Hodgkin's lymphoma further along the causal chain do not seem to be related to immune function or are related to aspects not affected by antiretroviral combination therapy. Because of the large number of susceptible patients with a history of severe immunodeficiency, the fall in the incidence of non-Hodgkin's lymphoma will probably lag behind that observed for other opportunistic diseases. Non-Hodgkin's lymphoma will thus remain a relatively common complication among patients treated with antiretroviral combination therapy.

We thank the patients for participating.

Contributors: BL initiated the study, performed statistical analyses, and participated in writing the paper. AT discussed core ideas and participated in clinical data collection and writing the paper. ME initiated the study, supervised statistical analyses, and wrote the first draft of the paper. BL and ME are the guarantors for the study.

Funding: Swiss Federal Office of Public Health (Grant No 3600.010.1).

Competing interests: None declared.

1 Egger M, Hirschel B, Francioli P, Sudre P, Wirz M, Flepp M, et al for the Swiss HIV Cohort Study. Impact of new antiretroviral combination therapies in HIV infected patients in Switzerland: prospective therapies in HIV infected patients

2 Mocroft A, Vella S, Benfield TL, Chiesi A, Miller V, Gargalianos P, et al for the EuroSIDA Study Group. Changing patterns of mortality across Europe in patients infected with HIV-1. Lancet 1998;352:1725-30.

3 Ledergerber B, von Overbeck J, Egger M, Lüthy R. The Swiss HIV cohort study: rationale, organization and selected baseline characteristics. Soz Praeventivmed 1994:39:387-94.

4 Goedert JI, Coté TR, Virgo P, Scoppa SM, Kingma DW, Gail MH, et al. Spectrum of AIDS-associated malignant disorders. Lancet 1998:351:1833-9.

5 Chang Y, Cesarman E, Pessin MS, Lee F, Culpepper J, Knowles DM, et al. Identification of herpesvirus-like DNA sequences in AIDS-associated Kaposi's sarcoma. Science 1994;266:1865-9.

(Accepted 19 January 1999)

\title{
Randomised controlled trial of long term efficacy of captopril on preservation of kidney function in normotensive patients with insulin dependent diabetes and microalbuminuria
}

\author{
Elisabeth R Mathiesen, Eva Hommel, Henrik P Hansen, Ulla M Smidt, Hans-Henrik Parving
}

Steno Diabetes

Center, DK 2860

Gentofte,

Copenhagen,

Denmark

Elisabeth R

Mathiesen,

consultant

Eva Hommel,

chief physician

Henrik P Hansen,

research fellow

Ulla M Smidt,

laboratory technician

Hans-Henrik

Parving,

professor

Correspondence to: Dr E R Mathiesen,

Medical Endocrine

Department,

University Hospital

of Copenhagen,

Rigshospitalet, 2100

Copenhagen $\varnothing$,

Denmark

em@rh.dk

BMJ 1999;319:24-5
In patients with insulin dependent diabetes, angiotensin converting enzyme inhibition delays the progression from microalbuminuria to diabetic nephropathy, but previous studies have been too short to show a preservation of kidney function. ${ }^{1-3}$ We assessed the effectiveness of angiotensin converting enzyme inhibition on preservation of kidney function in an 8 year prospective, randomised controlled trial.

\section{Patients, methods, and results}

Forty four normotensive patients with insulin dependent (type I) diabetes and persistent microalbuminuria $(30-300 \mathrm{mg} / 24 \mathrm{~h})$ were enrolled as previously described in detail. ${ }^{1}$ The treatment group $(n=21)$ was given captopril $(100 \mathrm{mg} / 24 \mathrm{~h})$ and bendrofluazide $(2.5 \mathrm{mg} / 24 \mathrm{~h})$. The 23 remaining patients were left untreated. Diabetic nephropathy was defined as albuminuria persistently $>300 \mathrm{mg} / 24 \mathrm{~h}$. Glomerular filtration rate was measured annually with Crom EDTA plasma clearance over 4 hours. ${ }^{1}$

After 4 years two patients in each group were excluded because they did not attend follow up sessions. Four of the patients in the control group started antihypertensive treatment with diuretics, $\beta$ blockers, or a calcium channel blocker. Three patients in the treatment group were changed from bendrofluazide to frusemide because of oedema or diastolic blood pressure $>95 \mathrm{~mm} \mathrm{Hg}$. After 8 years 16 of the 21 patients in the treatment group and two patients from the control group were subsequently investigated after a treatment pause of 2 months.

The proportion of patients who progressed to diabetic nephropathy was $40 \%(9 / 23)$ in the control group and $10 \%(2 / 21)$ in the captopril group (survival analysis $\mathrm{P}=0.019$ ). In the captopril group there was a significant increase in urinary albumin excretion $(\mathrm{P}<0.001)$ during the treatment pause. In six $(38 \%)$ of the 16 patients albuminuria exceeded $300 \mathrm{mg} / 24 \mathrm{~h}$.

Glomerular filtration rate in the captopril group declined from 126 (24) at baseline to $114(23) \mathrm{ml} / \mathrm{min}$ after 8 years but rose again to 126 (21) during the pause in treatment (table). Follow up values of glomerular filtration rate measured during the treatment pause were therefore used whenever available. The decline in mean glomerular filtration rate $(\mathrm{ml} / \mathrm{min})$ was $11.8(95 \%$ confidence interval 1.2 to $22.0 ; t$ test $\mathrm{P}$ value 0.03$)$ and $1.4(-4.9$ to $7.7 ; \mathrm{P}=0.65)$ in the control and captopril group, respectively $(\mathrm{P}=0.09$ between the groups). The fall in glomerular filtration rate during the 8 year study period in the 
Mean glomerular filtration rates $(\mathrm{ml} / \mathrm{min})$ in normotensive patients with insulin dependent diabetes at baseline, after 8 years' follow up, and during pause in treatment in captopril and control groups

\begin{tabular}{|c|c|c|c|c|c|c|}
\hline \multirow[b]{2}{*}{$\begin{array}{l}\text { Patient } \\
\text { No }\end{array}$} & \multicolumn{3}{|c|}{ Captopril group } & \multicolumn{3}{|c|}{ Control group } \\
\hline & Baseline & 8 Years & $\begin{array}{l}8 \text { Years } \\
\text { + pause }\end{array}$ & Baseline & 8 Years & $\begin{array}{l}8 \text { Years } \\
+ \text { pause }\end{array}$ \\
\hline 1 & 100 & 101 & 120 & 141 & $157^{*}$ & $135^{*}$ \\
\hline 2 & 129 & 125 & 131 & 156 & 131 & - \\
\hline 3 & 153 & - & - & 131 & 123 & - \\
\hline 4 & 96 & 75 & - & 96 & $39^{*}$ & $47^{*}$ \\
\hline 5 & 114 & 99 & $122^{*}$ & 87 & 84 & - \\
\hline 6 & 112 & 98 & $116^{*}$ & 132 & $106^{*}$ & - \\
\hline 7 & 105 & $105^{*}$ & $112^{*}$ & 154 & $68^{*}$ & - \\
\hline 8 & 127 & $145^{*}$ & $140^{*}$ & 151 & 143 & - \\
\hline 9 & 140 & 127 & 144 & 150 & 161 & - \\
\hline 10 & 108 & 70 & $102^{*}$ & 117 & 106 & - \\
\hline 11 & 169 & - & - & 111 & - & - \\
\hline 12 & 144 & 120 & 121 & 148 & 144 & - \\
\hline 13 & 117 & 104 & - & 118 & 119 & - \\
\hline$\overline{14}$ & 110 & 100 & 97 & 108 & $94^{*}$ & - \\
\hline 15 & 96 & 108 & - & 126 & 141 & - \\
\hline 16 & 171 & 151 & 166 & 142 & 168 & - \\
\hline 17 & 164 & 156 & $161^{*}$ & 145 & 130 & - \\
\hline 18 & 128 & 106 & 103 & 146 & 140 & - \\
\hline 19 & 104 & 116 & 105 & 122 & - $^{*}$ & - \\
\hline 20 & 130 & 135 & 146 & 117 & $91^{*}$ & - \\
\hline 21 & 132 & 122 & 128 & 120 & $112^{*}$ & - \\
\hline 22 & - & - & - & 136 & $130^{*}$ & - \\
\hline 23 & - & - & - & 120 & 118 & - \\
\hline Mean (SD) & $126(24)$ & $114(23)$ & $126(21)$ & $129(18)$ & 119 (32)† & - \\
\hline
\end{tabular}

*Patient developed diabetic nephropathy during 8 years of follow up or during treatment pause.

†Difference from baseline significant at $\mathrm{P}=0.03$.

eight control patients who developed nephropathy was 27.3 (3.7 to 51.0; $\mathrm{P}=0.03$ ) while glomerular filtration rate increased by 3.8 ( -3.5 to 11.0$)$ in the six patients treated with captopril with urinary albumin excretion $>300 \mathrm{mg} / 24 \mathrm{~h}$ during the treatment pause $(\mathrm{P}=0.02$ between the groups). Haemoglobin $A_{1 c}$ and blood pressure did not differ between the two groups at any time during the study.

\section{Comment}

Our study has shown that the beneficial effect of angiotensin converting enzyme inhibition in the prevention of diabetic nephropathy is long lasting and associated with preservation of normal glomerular filtration rate. To obtain a valid determination of the rate of decline in glomerular filtration rate the applied glomerular filtration rate method should have a good accuracy and precision and the observation period should exceed 2 years. ${ }^{4}$ These requirements have been fulfilled in our study in contrast with previous studies. ${ }^{2}{ }^{3}$ The second part of the study showed a return in glomerular filtration rate to the values before treatment after 2 months of withdrawal of antihypertensive treatment. The temporary fall in glomerular filtration rate in the intervention group was therefore regarded as a reversible haemodynamic phenomenon. Patients with persistent microalbuminuria at follow up had a stable normal glomerular filtration rate. ${ }^{5}$ The clinically significant effect of angiotensin converting enzyme inhibition on preservation of normal glomerular filtration rate was related to prevention of progression from micro- albuminuria to diabetic nephropathy in patients with insulin dependent diabetes.

Contributors: HHP had the original idea for the study. ERM and HHP were responsible for conducting the study and interpreting the results and are guarantors. ERM and EH conducted the clinical evaluation during the 8 years of study. HPH and ERM conducted the clinical evaluation during the treatment pause. UMS performed the assessments of glomerular filtration rate. All authors participated in the interpretation of the results and reporting.

Funding: ERM was funded by a senior research fellowship from the University of Copenhagen. Steno Diabetes Center supplied us with equipment for glomerular filtration analysis and laboratory tests. Squibb donated the tablets and a 1 month research fellowship for ERM.

Competing interests: None declared.

1 Mathiesen ER, Hommel E, Giese J, Parving H-H. Efficacy of captopril in postponing nephropathy in normotensive insulin dependent diabetic patients with microalbuminuria. BMJ 1991;303:210-6.

2 Viberti G, Mogensen CE, Groop LC, Pauls JF. Effect of captopril on progression to clinical proteinuria in patients with insulin dependent diabetes mellitus and microalbuminuria. JAMA 1994;271:275-9.

3 Laffel LMB, McGill JB, Gans DJ. The beneficial effect of angiotensinconverting enzyme inhibition with captopril on diabetic nephropathy in normotensive IDDM patients with microalbuminuria. Am J Med 1995;99:497-504.

4 Levey AS, Gassman J, Hall PM, Walker WG. Assessing the progression of renal disease in clinical studies: effects of duration of follow-up and regression to the mean. JAm Soc Nephrol 1991;1:1087-94.

5 Mathiesen ER, Feldt-Rasmussen B, Hommel E, Deckert T, Parving H-H Stable glomerular filtration rate in normotensive IDDM patients with stable microalbuminuria: a 5 year prospective study. Diabetes Care 1997;20:286-9

(Accepted 31 December 1998)

\section{Corrections and clarifications}

Ingestion of mouthwash by children

This letter by Tamsin Wade and Alison Gammon (17 April, p 1078) wrongly stated that "The mouthwash ... was a supermarket 'extra strength' own brand which contains $37 \%$ alcohol." It should have stated that this type of mouthwash "may contain up to $37 \%$ alcohol." The manufacturers of the mouthwash have informed the authors that it contained about 20-25\% alcohol, which is still far more than what one would expect a child to have access to.

Book reviews

In William Stoney's review of Ira M Rutkow's American Surgery: An Illustrated History (17 April, p 1082) William Stewart Halsted's surname was spelt incorrectly. In Alex Brooks' review of Jared Diamond's Guns, Germs and Steel (8 May, p 1294) the Inca emperor Atahualpa's name was spelt incorrectly and his empire was wrongly described as Aztec.

Website of the week

In his review of the NHS Direct website (24 April, p 1152) Douglas Carnall gave the wrong number for NHS Direct's telephone service: it is 08454647 (or $08454 \mathrm{NHS}$ on alphanumeric telephones). A copy of Tony Blair's speech about government plans to expand the service is available at the No 10 website (www.number-10.gov.uk/public/news/ index.html).

Obituaries

In the obituary of Professor Henry Taylor Howat (8 May, p 1292) Professor Howat's surname was spelt incorrectly. 